\title{
State Interventionism in Foreign Trade
}

\author{
Ewa Szymanik \\ Cracow University of Economics, Cracow, Poland
}

\begin{abstract}
The paper refers to literatures to show how the state mitigates the effects of market failures in foreign trade. The research study leads to the conclusion that state interventions are necessary in creating administrative and legal conditions for facilitating trade exchange in the context of the role of transnational corporations in the global economy, as well as in reducing the adverse impact of international turbulences on the competitiveness of national entities through the use of export supporting instruments.
\end{abstract}

Keywords: foreign trade, state interventionism, market inefficiency, export

\section{Introduction}

The Great Depression highlighted the weaknesses of a free market economy. Economists had reminded about the inefficient market hypothesis developed by Launhardt (Ritzmann, 1983) at the end of the 19th century, as well as about mercantilists' postulates regarding the protection of markets against foreign competition and state support for industrialisation (Bochenek, 2010). It was just a starting point for further analyses and new proposals for counteracting negative phenomena. The recovery measures were proposed by Keynes, who recommended transforming the state into an active investing entity. Government programmes were to be treated not as permanent components of an economic system but temporary measures in those areas in which private enterprises were not inclined to engage. Such views were also accepted after the war, attributing to macroeconomic policies, referred to as adjustments, the ability to support market mechanisms (Bochenek, 2010; Wojtyna, 1988; Wojtyna, 2000).

State interventions were also designed to support foreign trade activities. The views advocated by mercantilists were abandoned, but protectionist activities have recurred in the recent years (Szymanik, 2017b), which implies that entrepreneurs who operate in overseas markets require state intervention. Economic realities are trading conditions which are not created by a free market but international agreements, as well as by an increasing impact of international corporations which exert pressure on particular countries, resulting in the opposition of smaller market players who require state intervention.

The paper presents a review of literatures to show the ways in which the state attempts to mitigate the effects of market inefficiency in foreign trade through interventions, thus responding to market failures at national and international levels. The research method is a literature analysis.

\section{The Main Areas of Market Inefficiency}

The basic types of market inefficiencies are defined by Stiglitz (2004). Some of them are:

Ewa Szymanik, Ph.D., Department of Microeconomics, Cracow University of Economics, Cracow, Poland.

Correspondence concerning this article should be addressed to Ewa Szymanik, Cracow University of Economics, Rakowicka 27, 31-510 Cracow, Poland. 
- Competition - its limitations lead to economic inefficiency (as understood by Pareto), related to reductions in production and resulting in losses of prosperity;

- External effects related to the impact of activities on entities, not carried out by these entities (including both benefits and costs).

- Incompleteness or lack of a given market.

- Resulting from incomplete information, leading to negative selection or the risk of abuse of knowledge by a better informed entity (Giza, 2013).

- Macroeconomic - unemployment, inflation, budget deficit, or market disequilibrium.

Frey identifies various types of inefficiencies. In his opinion, they result from the following situations (Bochenek, 2010):

- The imposition by a given entity of the level of costs which is not accepted by a business partner (as a result of a strong position).

- The state's guarantee of access to specific resources - other entities cannot affect it and, consequently, exert influence on the market.

- Monopolisation of a given market as a result of economies of scale achieved by particular companies.

- Fear of the effects of excessive risk, leading to the low dynamics of market development, etc.

\section{State Interventionism-A Response to Market Inefficiency}

The state's impact on an economy was to be treated as a response to the above inefficiencies. Although Frey claims that it is the domination of private markets that is a source of social prosperity, the effective functioning of a price system results from the existence of relevant institutions which introduce and execute specific rights (e.g., ownership rights), and such activities are conditioned by the existence of a strong state. He also stresses that state interventionism is not always appropriate in the case of market failures. He claims that in a given situation it is necessary to carry out a comparative analysis of market and state intervention-related costs, because such intervention is not designed to directly and manually steer an economy but to establish the rules of an economic game - framework conditions for the activities of private entities (Frey, 1992; Bochenek, 2010).

This approach fits in perfectly with the principles of the functioning of foreign trade. Market inefficiency resulting from the imposition by a given entity of unacceptable costs or trading terms in its relations with business partners (accompanied by the lack of transparency resulting from cultural differences or various interpretations of a given clause of an agreement) indicated the need for introducing unified principles and regulations, which was only possible at a state level. It applies not only to various clauses (e.g., the most-favoured nation clause, which indicates that goods from a given country should not be treated less favourably than those which are offered by the most-favoured partner) but also to technical standards and terms of delivery (e.g., Incoterms). Such measures taken by the state facilitate the process of negotiations with foreign partners.

The main reason for implementing export policies as a response to inefficient market mechanisms in a global scale and to market distortions can be referred to Bhagwati's (2013) theory. It identifies two basic groups of distortions: domestic and international distortions, and economic and non-economic ones. According to this classification, distortions occur both in domestic and global markets. The first category can be related to government economic policies (especially customs and tax policies), internal market mechanisms, or high inflation rates. The other category of distortions can be caused by protectionist or dumping policies. Such 
conditions necessitate implementing export-oriented policies - the lack of state interventionism can lead to exporters' discrimination in world markets.

Excessive interventionism, on the other hand, is a great mistake regardless of the region where it is adopted. According to Wróblewski (2013), a number of economic terms lose their original meaning, for example, export, until recently regarded as a major indicator of the state's international position, is of much less significance today in favour of the quality of concluded transactions. The author recommends that the significance of trade be measured on the basis of intellectual value added. He does not propose any measuring methods, which diminishes the value of his research, but his reasoning seems to be correct.

\section{The State Interventionism and Foreign Trade}

Market inefficiencies, especially those resulting from external factors, necessitate state interventionism in the area of foreign trade. Because one of the state's tasks is to create favourable conditions for corporate development, state intervention is fully justified in this field.

It should be noted that debates on foreign trade conditions go back to Smith's works. He was in favour of free trade exchange, and rejected the main concepts of mercantilism, claiming that the balance of trade was less significant than the balance of production and consumption - the major factors affecting current business cycles. He believed that protectionism led to economic inefficiency and reductions in, or even loss of, competitive advantage in domestic companies enjoying state protection. In such conditions, only free trade could be beneficial for countries, facilitating development and economic growth. Smith was also against levying duties on less expensive imported goods, accepting such exemptions as countervailing, repressive, and fiscal duties as measures against the threat posed by overseas companies to national security, production, and labour markets (Kundera, 2011).

It should be stressed that foreign trade should not be referred to only one type of market inefficiency. A number of factors overlap: inefficient competition (An increasingly significant role is played by transnational corporations which impose their business terms not only on particular enterprises but also entire countries), external factors related to more expensive imported goods (especially consumer goods), or macroeconomic distortions resulting from one of unemployment types (caused by low internal demand levels). Another significant issue is asymmetric access to information.

Empirical data indicate that after World War II, the scope of state interventionism has increased considerably, and this trend seems to continue. This problem was addressed by Friedman. In a number of countries (mainly highly developed nations), a large portion of income is spent as a result of state administrative decisions. According to Giza (2013), it results from the combined impact of economic policies and the evolution of the determinants of a broadly understood social and economic system.

This trend is also visible in foreign trade. Global trade volumes rise, and the number of business relations between geographically and culturally distant countries increases steadily. It is the state that initiates negotiations aimed to ensure better trading terms for small companies.

Obviously, it does not imply that trade transactions cannot be concluded without agreements between countries. Usually, business relations are initiated by business cooperation between individual enterprises, but then they carry the burden of negotiations with much larger entities, having to accept the rules and principles imposed by a foreign country's administrative decisions. They range from the imposition of high customs duties (preferential or discriminatory) to non-customs regulations (which can be even more harmful). 
It should be noted that even entering into trade liberalising international or bilateral agreements does not fully protect exporters and importers against discriminatory measures - a prevailing trend to protect own markets and apply various non-tariff barriers (Szymanik, 2017a; Wajda-Lichy, 2014). It should be stressed that as a result of the economic downturn a number of researchers, witnessing particular countries' tendency to protect their own markets, changed their original definitions of protectionism (Bown \& Crowley, 2012; Kee, Neagu, \& Nicita, 2013), pointing to such trade restrictions as tariffs, quotas, import bans, and export taxes. The role of such restrictions gains in significance as compared with the pre-crisis period, when more importance was assigned to such instruments as government procurement, technical standards, competitive tendering, or requirements related to preferences to the purchase of domestic goods (Kee, Neagu, \& Nicita, 2013, Evenett \& Vines, 2012, Baldwin \& Evenett, 2012).

Numerous barriers are internal restrictions, hindering trade exchange. They include technical obstacles, export subsidies, administrative regulation related to competitive tendering, sanitary and phytosanitary regulations, restrictions resulting from environmental activities, etc.(Global Trade Alert, 2016).

It should be noted that EU member states, as compared with other countries, have not made a frequent use of protectionist policies.

The most severe restrictions include those justified by the protection of trade and security issues, government aid programmes, and the taxation of imported goods. Because barriers are adopted simultaneously and their impact accumulates leading to further restrictions, the competitiveness of particular countries decreases, hindering international trade, the process of economic recovery, as well as reducing the pace of economic growth. The long-term consequences can hardly be estimated.

It should be noted that the use of trade barriers does not stimulate economic development and competitiveness, hence the inclination to protect domestic markets, accompanied, however, by the need for liberalising entry regulations. Because the significance of bilateral and multilateral agreements increases in the global economy, EU countries have also decided to engage in this process. In this context, one of the most important initiatives is an agreement on establishing a free trade zone between the EU and Japan (negotiations started in March 2013), aimed to increase the EU's GDP by 0.21\% (Benz \& Yalcin, 2015). This slight increase is likely to result from the lower competitiveness of EU products, especially technologically advanced goods.

In this context, it would be worth a while to refer to controversial Canada-EU Trade Agreement (CETA) and Transatlantic Trade and Investment Partnership (TTIP) agreements (Szymanik, 2017a). However, a broader analysis of this issue would go beyond the scope of this work.

The problem of increased protectionism can be related to unequal access to information-one of the causes of market inefficiency. There are a number of factors which affect companies' access to information about overseas markets. Simultaneously, companies differ in terms of their ability to overcome market entry barriers. Obviously, the greatest obstacles are faced by companies entering into international cooperation for the first time. Some other barriers include frequent changes in economic and government regulations, direct government intervention, difficult access to reliable information, and, in some cases, cultural differences and business practices, as well as political risk. Large companies have a greater ability to overcome such barriers, while smaller entities frequently abandon their plans to penetrate new markets for fear of unexpected difficulties and the high costs of reaching new customers, as well as the risk of the takeover of their customers by competitors (Gawin, 2008). 


\section{The Promotion of Export-The State's Response to Market Inefficiency}

All countries undertake efforts to implement export-oriented policies, which indicate governments' influence on international exchange. In a narrow sense, such policies can be understood as sets of regulations, methods, and tools adopted by governments with a view to boosting exports (Rosati, 1990), while in a broad sense, they are treated as economic policies aimed at achieving a country's accelerated sustainable development thanks to export activities (Bombińska, 2014). There are various types of export support tools. Currently, they are implemented by export supporting institutions.

Such institutions operate in a number of countries, e.g., United Nations Conference on Trade and Development (UNCTAD) identifies export supporting entities in more than a hundred or so countries. Some of these institutions are also engaged in trade promotion, foreign investment and the development of entrepreneurship (Gawin, 2008).

WTO members are required to implement relevant export support policies which relate, in particular, to the use of export subsidies (similarly to accession to the EU). In practice, it indicates easier access to overseas markets but, on the other hand, the necessity of abandoning, or rigorous restriction of, some of the previously adopted tools (Bombińska, 2014). It should be noted that we deal here with, so to say, market failures which are secondary in character - in the beginning the state reacted to the inefficiencies of international trade exchange, and then it turned out it was necessary to make adjustments to the already implemented changes.

In the context of the complexity of such correlations, attention should be given to the government's major foreign trade intervention tool - the promotion of exports. The institutions which deal with these issues carry out activities in all EU member states.

The effectiveness of promotion expenses depends on a number of factors, such as a country's social and economic situation and its economic development potential (A country's economic advancement should be considered), economic policy objectives, corporate sector expectations, the assessment of hitherto pro-export activities, and external economic conditions. Also, it should be borne in mind that despite a positive correlation between the volume of export support expenses and the size of exports, research studies indicate that after achieving a certain level the effectiveness of such expenses is limited (especially in the case of highly developed countries) (Gawin, 2008).

This issue gains in significance in the context of an increasing number of countries (as already mentioned) which implement trade restricting policies. WTO data indicate that from 2008 to May 2016, such restrictions amounted to 2,835, with a mere 708 being lifted. It also applies to EU member states, e.g., Hungary's quality assurance tax (being, in fact, a hidden retail sales tax), or Romania-imposed regulation which states that more than half of the assortment of products in retail chains should originate from domestic businesses and be appropriately displayed. Another example is the requirement imposed in several countries to implement minimum wages for transport services in their territories (Wedziuk, 2017).

The issues of effective export support policies are discussed in literatures, also playing an important role in business practices. Therefore, they deserve attention from the perspective of the adopted tools, which can be divided into two main groups (Gorynia, 1996):

- Foreign trade policy (trade and FX policy tools).

- General economic policy (tax and credit policies, reflected in supporting export activities through tax and credit preferences, without discriminating business entities or specific goods). 
Another common classification identifies treaty-related activities, economic and financial instruments, and information and promotional support tools (Pierzchlewski, 2011). The first group of instruments, implemented by government superior bodies, comprises those of strategic significance, affecting access to overseas markets as well as the legal framework for implementing foreign trade policies (their justifiability is discussed above). They include the following:

- Establishing political and treaty relations at the governmental level.

- Membership in international organizations.

- Entering into trade and group integration trade agreements.

The other category of export support instruments includes the following economic and financial instruments:

- Exchange rates.

- Subsidies and tax exemptions.

- Lending instruments (e.g., governmental export preferential loans, loans granted by commercial banks to importers or their banks (so called combined aid programmes), trade credit, and interest subsidy payments.

- Insurance instruments (including insurance companies' guarantees granted to the institutions which offer credit export facilities, foreign investment insurance, and risk hedging (higher production costs, exchange risk, etc.) (Bednarczyk, 2000; Mańczak, 2013).

The third type of export support measures comprises promotion and information tools. On the one hand, they comprise activities aimed to promote a country in a macroeconomic dimension, that is to create its positive image as a business partner, and to support the promotion activities of particular companies through co-financing exhibitions and promotion campaigns, and, on the other hand, undertakings aimed to provide comprehensive information about market conditions through, among others, relevant publications of collected information. Such activities are usually carried out by dedicated agencies.

As already mentioned, market failures in foreign trade are corrected by specialised institutions. In Poland, the original initiatives in this area are undertaken by the Ministry of Development. The Ministry has developed a project which sets priorities for industrial policies for the years 2015-2020+ (Project, http://konsultacje. gov.pl/node/3692). It includes a plan for expanding activities in overseas markets through a more effective access to the EU's internal market, which is facilitated by creating appropriate administrative conditions.

Attempts to correct market inefficiencies are mainly vested in the hands of the Ministry of Development. It appoints entities which implement relevant programmes, or commissions tasks to existing institutions. In accordance with the above presented classification of the types of support, two groups of institutions can be identified (http://trade.gov.pl).

The first group comprises the organizations which offer professional support:

- Promotion and Investment Promotion Departments of the Embassies and Consulates of the Republic of Poland (WPHI), acting as the overseas representatives of the Minister of Development, supporting Polish enterprises.

- Overseas Commercial Offices of the Polish Agency for Investment and Trade-similar tasks to those above, and supporting Polish investors abroad and foreign investors in Poland.

- Polish Agency for Investment and Trade.

- Polish Champion Programme, which creates groups of leaders for overseas expansion among Polish private enterprises. Its participants learn to identify barriers to expansion, develop good practices in business, and receive support in foreign investment projects from Polish public authorities. 
- GoChina and GoAfrica Programmes, offering assistance to companies in researching potential markets and distribution channels, establishing local contacts, verifying business partners, and assisting companies in arranging fairs and business missions and meetings.

- Association of Polish Exporters.

- National Chamber of Commerce, cooperating with the Government (accompanying business delegations representing the Ministry of Development and the Ministry of Foreign Affairs) and its agencies under international projects.

- Centres for Investor and Exporter Services (COIE), offering professional assistance to exporters-15 entities which offer various forms of free information-related assistance.

- Chambers of commerce - voluntary associations of entrepreneurs.

- Polish Agency for Enterprise Development, engaged in implementing national and international projects financed by structural funds, state budget and European Commission long-term programmes.

- Polish Chamber of Commerce of Importers, Exporters and Cooperation, representing the interests of companies operating in these business areas.

The other group comprises institutions which offer financial support:

- Ministry of Finance, responsible for granting government loans for financing the supplies of goods from Poland.

- Bank Gospodarstwa Krajowego/Bank of National Economy is a state bank for development, engaged in financing major infrastructure investment projects, and stimulating corporate development in the domestic and overseas markets.

- Polish Development Fund - a state capital group mainly engaged in supporting export activities and entrepreneurship as well as advising and promoting Polish enterprises in international markets.

- Korporacja Ubezpieczeń Kredytów Eksportowych Spółka Akcyjna/Export Credit Insurance Corporation, offering trade insurance to Polish entrepreneurs as well as services ensuring secure trade transactions in Poland and overseas markets. Its activities focus on insuring deferred payment trade receivables and granting insurance guarantees. It is the only insurance company in Poland entitled to offer export insurance guaranteed by the State Treasury, ensuring the security of trade transactions in high political risk markets. The Corporation is the only entity in Poland which insures long-term export investment projects with two-year or longer maturities.

- Regional Financing Institutions - the regional partners of the Polish Agency for Enterprise Development - cooperating in the implementation of schemes which target micro businesses and SMEs.

On January 1, 2017, the Polish Investment and Trade Agency established for the purpose of making an effective use of the existing pro-export, pro-investment, and promotion resources. The Agency will be responsible for developing export and foreign investment support strategies, implementing Polish economy promotion policies, developing advisory services for exporters, and expanding the scope of export activities. Moreover, the liquidated Trade and Investment Promotion Departments are to be replaced by Trade Offices, which are designed to effectively meet exporters' expectations (http://mr.gov.pl)—It is planned to establish 69 outlets, especially in "prospective non-European markets" (e.g., India, Iran, Mexico, and Vietnam), and the programme is to be enhanced by intensified promotion campaigns, partially relying on proven solutions (e.g., Expo fairs) (Osiecki, 2016). In addition to that, the Ministry of Development has launched promotion campaigns for 12 selected sectors, and an on-line information campaign dedicated to promoting the Polish Economy Brand, aimed at creating a positive image of the Polish economy in overseas markets (http://mr.gov.pl). The 
effectiveness of all these measures, however, depends on entrepreneurs' willingness to take advantage of them. The results of long-lasting research studies conducted by Instytut Badań Rynku, Konsumpcji i Koniunktur (IBRKK) point to the limited awareness of particular support instruments, especially institutional ones (E. Szymanik \& M. Szymanik, 2005). A research study conducted by the University of Economics in Poznan indicates that $30 \%$ of the analysed entities make use of the offered support instruments (A similar proportion is recorded in other countries). Exporters are more inclined to rely on their own experience or Internet information. A number of enterprises are not even aware of the fact that major government institutions (Export Promotion Portal, Polish embassies, and PARP) offer assistance in carrying out international operations (Bartosik-Purgat, Mruk, \& Schroeder, 2013). It is a major barrier to the state's effective activities aimed to correct market inefficiencies in foreign trade.

The effectiveness of newly established institutions can be hindered by a number of factors, reducing their ability to correct market failures. The most frequent adverse factors - which also occur in export promoting institutions in other countries - include unfavourable external conditions (the business partners' protection of their own markets), the lack of information about available assistance programmes, excessive bureaucracy, management errors, or the excessive authority of various institutions. Also, what is missing is something that can be referred to as economic diplomacy—politicians' failure to understand their indispensable role in establishing a great number of trade relations (Bryła, 2017).

\section{Concluding Remarks}

An analysis of theoretical works indicates that they focus on the effects of market inefficiency on a country's internal market without consideration given to a broader international perspective. It is an analysis of the selected types of market failures that could allow for presenting the international aspects of the problem, referring them to such an area as foreign trade. Therefore, it would be necessary, in the conditions of increasing globalization and the interdependence of particular economies, to broaden the scope of research by analysing various types and impact of market inefficiency in an international dimension.

An ever-increasing role of transnational corporations is one of the reasons for which state interventionism in creating administrative and legal conditions for developing trade exchange should not be assessed only negatively. Without responsible government policies economies would be dependent on corporations' arbitrary decisions. Although a free-market economy is regarded to be the most efficient regulator, it tends to behave in a disorderly manner, not giving consideration to social and economic goals. Therefore, state interventions can put various situations in some sort of order, setting desirable directions for strategic and social development. However, it does not imply that the state is the only expert-decision-makers do make mistakes, so the state should focus on improvements in administration and law, which is recommended by Polish entrepreneurs (Horbaczewski, 2016). Enterprises in Poland often stress the need for extending the scope of state activities and providing easier access to economic tools and credit facilities as the major drivers of the development of export. However, the achievement of these goals is hindered by such factors as the fear of dependence on overseas markets and their business, a great burden on the central budget resulting from financial incentives, or possible overseas business partners' retaliatory response.

It should be borne in mind that because market inefficiencies occur at national as well as international levels, and governments - acting independently - have limited impact on transnational market distortions, countries are often forced to resort to export support instruments to enhance the competitiveness of domestic 
enterprises (Mańczak, 2011). Without state interventionism, trade exchange would be carried out in less favourable conditions. It also applies to creating a friendly environment for foreign direct investment, for example, Poland's accession to the EU indicated the inflow of foreign capital, which had implications for further international trade exchange. Without trade agreements and state regulation breakthrough changes would not have been possible. ${ }^{1}$

The above considerations can be concluded by two quotes. The first one (Carden \& Horvitz, 2014) is a statement of general character: the criticism of market failures does not justify ipso facto government intervention, and the only reliable way of defining a market failure as the actual "failure" is referring it to an unachievable theoretical ideal (...) markets are not always perfect. The other quote comes from Giza (2013), who claims that a market, similarly to all other mechanisms, has its limitations-They can be identified on condition that we identify the indications of their failure; in some cases, they are so significant that it seems desirable to implement correcting and restricting measures in specific areas.

Foreign trade seems to be such an area.

\section{References}

Baldwin, R., \& Evenett, S. J. (2012). Beggar-the-neighbour policies during the crisis-era: Causes, constrains and lessons for maintaining open borders. Oxford Review of Economic Policy, 28(2), 211-234.

Bartosik-Purgat, M., Mruk, H., \& Schroeder, J. (2013). Wykorzystanie instytucjonalnych źródeł informacji w działalności polskich eksporterów. Marketing i Rynek, (7), 18-21.

Bednarczyk, T. H., (2000). Instrumenty wspierania eksportu. Warszawa: Kredyty i ubezpieczenia, PWN.

Benz, S., \& Yalcin, E. (2015). Productivity versus employment: Quantifying the economic effects of an EU-Japan Free trade agreement. The World Economy, 38(6), 935-961.

Bhagwati, J. (2013). Wolny handel dziś. Warszawa: CeDeWu.

Bochenek M. (2010). Bruno S. Frey i Joseph E. Stiglitz o zawodności państwa i zawodności rynku, "Ekonomia i Prawo". Wydawnictwo Naukowe UMK, VI, 72-73, 81, 83.

Bombińska, E. (2014). Możliwości wspierania eksportu w świetle międzynarodowych zobowiazań Polski. Kraków: Zeszyty Naukowe UEK w Krakowie.

Bown, C. P., \& Crowley, M. A. (2012). Import protection, business cycles and exchange rates: Evidence from the Great Recession. Journal of International Economics, 90(1), 50-64.

Bryła, E. (2017). Polski eksport słabo rośnie. W handlu żywnością coraz większy import. Gazeta Wyborcza, February 15, 2017.

Carden, A., \& Horvitz, S. (2014). Czy zawodność rynku to dostateczny powód dla rzqdowej interwencji? Retrieved from http://mises.pl/blog/2014/01/09/carden-horwitz-czy-zawodnosc-rynku-dostateczny-powod-dla-rzadowej-interwencji/

Evenett, S. J., \& Vines, D. (2012). Crisis-era protectionism and the multilateral governance of trade: An assessment. Oxford Review of Economic Policy, 28(2), 195-210.

Frey, B. (1992). Transformation-What is the role of the state? Seminar Papers, (8), 11-12.

Gawin, G. (2008). Instytucje promujące eksport-Wybrane aspekty funkcjonowania. Wspólnoty Europejskie, (5), 32-33, 37-40.

Giza, W. (2013). Zawodność rynku. Powstanie i rozwój idei. Kraków: Wydawnictwo UEK w Krakowie.

Global Trade Alert. (2016). Global Trade Alert database. Retrieved from http://www.globaltradealert.org

Gorynia, M. (1996). Międzynarodowa konkurencyjność polskiej gospodarki a polityka ekonomiczna. Ekonomista, (3), $347-348$.

Horbaczewski, S. (2016). Za dużo ingerencji w biznes. Rzeczpospolita, August 17, 2016.

Kee, H. L., Neagu, C., \& Nicita, A. (2013). Is protectionism on the rise? Assessing national trade policies during the crisis of 2008, The Review of Economics and Statistics. Retrieved https://www.parisschoolofeconomics.eu/IMG/pdf/Protectionism_KNN.pdf

Kundera, E. (2011). Państwo w gospodarce w ujęciu doktryny liberalnej. In U. Kalina-Prasznic (Ed.), Państwo i rynek. Obszary zawodności (pp. 24-25). Wrocław: Gaskor.

\footnotetext{
1 Also, attention should be given to other factors, not affected by the state, including growth stimulating business cycles.
} 
Mańczak, G. (2011). Instrumenty wspierania produkcji eksportowej, "Folia Pomeranae Universitatis Technologiae Stetinensis". Oeconomica, Szczecin, 291(65), 95-102.

Mańczak, G. (2013). Ocena polityki proeksportowej w Polsce, "Polityka Ekonomiczna". Wrocław: Wydawnictwo UE we Wrocławiu.

Osiecki, A. (2016). Polskie marki ruszają w świat. Rzeczpospolita, October 24, 2016.

Pierzchlewski, W. (2011), Polityka państwa $w$ zakresie wspierania aktywności matych i średnich przedsiębiorstw $w$ handlu międzynarodowym Polski. Wrocław: Wydawnictwo UE we Wrocławiu.

Ritzmann, F. (1983). Bedeutende Oekonomen und ihre Werke (Dogmenhistorische Chronik). Zürich: Zentralstelle der Studentenschaft Zürich.

Rosati, D. (1990). Polityka proeksportowa. Warszawa: PWE.

Stiglitz, J. (2004). Ekonomia sektora publicznego. Warszawa: PWN.

Szymanik, E. (2017a). Bariery pozataryfowe jako nowy czynnik wplywajacy na konkurencyjność międzynarodowa, "Studia Ekonomiczne”. Katowice: Zeszyty Naukowe Uniwersytetu Ekonomicznego w Katowicach.

Szymanik, E. (2017b). Konkurencyjność eksportu—Nowe czynniki, “Przegląd Zachodni”. Poznań, 363(2), 189-204.

Szymanik, E., \& Szymanik, M. (2005). Wybrane czynniki wpływające na konkurencyjność eksportu polskich artykułów przemysłowych do krajów UE. In S. Pangsy-Kania and G. Szczodrowski (Eds.), Polska gospodarka w UE: innowacyjność, konkurencyjność, nowe wyzwania (pp. 317-323). Gdańsk: Fundacja Rozwoju Uniwersytetu Gdańskiego.

Wajda-Lichy, M. (2014). Traditional protectionism versus behind-the border barriers in the post-crisis era: Experience of three groups of countries - the EU, NAFTA and BRICS. Journal of International Studies, 7(2), 145-150.

Wedziuk, S. (2017). Protekcjonizm hamuje polski eksport. Retrieved from https://www.pb.pl/protekcjonizm-hamuje-polski-eksport-857549

Wojtyna, A. (2000). Ewolucja keynesizmu a główny nurt ekonomii. Warszawa: PWN.

Wojtyna, A. (1988). Nowe trendy w zachodniej teorii ekonomii. Kraków: AE w Krakowie.

Wróblewski, T. (2013). Gdy rozum śpi, budzą się keynesiści. Forbes, January 24, 2013. 